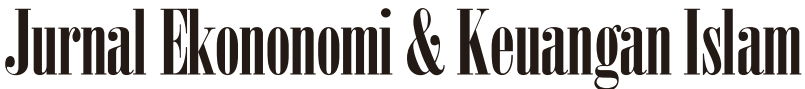

\author{
Available at http://journal.uii.ac.id/index.php/jeki
}

\section{Analisis regional keuangan inklusi perbankan syariah terhadap ketimpangan pendapatan di Indonesia}

Prastowo

Fakultas Ekonomi, Universitas Islam Indonesia, Yogyakarta

e-mail: prastowo@uii.ac.id

Keywords:

financial inclusion, Income inequality

DOI:

10.20885/JEKI.vol4.iss1.art6

\begin{abstract}
Indonesia as a Muslim dominated country has problem in high level of income inequality. In this regards, promoting financial inclusion in Islamic banking is argued to overcome problem of inequality in income distribution, especially for poor Muslim people. The spirit of financial inclusion and Islamic banking are expected to serve the goal of Islamic teaching on social justice, inlusion and distributiong resources between the rich and the poor. Nevertheless, the number of studies in the field of financial inclusion in Islamic banking still limited. Therefore, this research is aimed at observing the impact of financial inclusion in Islamic bank on income inequality in 33 provinces in Indonesia. This research applies financial inclusion index (FII) and Panel Least Squares which cover 2014 to 2016. Based on the result, it can be shown that financial inclusion in Islamic banking have significantly negative relationship with Gini index. Financial inclusion in Islamic banking contributes to reduce income inequality in Indonesia.
\end{abstract}

\begin{abstract}
Abstrak
Indonesia sebagai negara yang didominasi muslim memiliki masalah pada tingkat ketimpangan pendapatan yang tinggi. Dalam hal ini, mempromosikan inklusi keuangan dalam perbankan Islam dikemukakan untuk mengatasi masalah ketimpangan dalam distrbusi pendapatan, terutama bagi orang-orang Muslim yang miskin. Semangat inklusi keuangan dan perbankan syariah diharapkan untuk melayani tujuan pengajaran Islam tentang keadilan sosial, inklusi dan distribusi sumber daya antara yang kaya dan yang miskin. Namun, jumlah studi dibidang keuangan inklusi dalam perbankan Islam masih terbatas. Oleh karena itu, penelitian ini bertujuan untuk mengamati dampak inklusi keuangan di bank syariah pada ketimpanagn pendapatan di 33 provinsi di Indonesia. Penelitian ini menggunakan financial inclusion index (FII) dan panel Least Square yang mencakup tahun 2014 hingga 2016. Berdasarkan hasil tersebut, dapat ditunjukkan bahwa inklusi keuangan perbankan syariah memiliki hubungan negatif signifikan dengan indeks Gini. Inklusi Keuangan pada perbankan syariah berkontribusi menurunkan ketimpangan pendapatan di Indonesia.
\end{abstract}

\section{Pendahuluan}

Hal dasar yang membedakan antara kemiskinan dengan ketimpangan distribusi pendapatan terletak pada cakupan objek. Fokus pembahasan kemiskinan menitik beratkan pada masyarakat yang memiliki pendapatan dibawah ambang garis kemiskinan yang ditetapkan secara absolut (contoh: minimal konsumsi kalori) dan secara relatif (contoh: gaya hidup di lingkungan masyarakat). Namun, pada dasarnya seseorang dikatakan sebagai orang miskin apabila penghasilan yang didapat tidak mampu untuk memenuhi kebutuhan dasar seperti makanan, pakaian, pendidikan, kesehatan dasar, dan rumah yang layak (Pramanik, 1997). Menurut Organization of Economic Cooperative and Development (OECD) dan Todaro dan Smith (2015), ketimpangan pendapatan didefinisikan sebagai perbedaan dalam distribusi kekayaan dan pendapatan antar individu dalam masyarakat. Cakupan ketimpangan pendapatan lebih luas karena dapat menggambarkan kondisi masyarakat pendapatan golongan kaya, sedang dan miskin (Haughton \& Khandker, 2009).

Islam dalam hal ini memiliki perhatian khusus dalam permasalahan ketimpangan pendapatan. Ketimpangan pendapatan memiliki dampak dalam kehidupan ekonomi dan sosial (Berg \& Ostry, 2011; Berg, Ostry, \& Zettelmeyer, 2012; Ostry, Berg, \& Tsangarides, 2014, (Dabla-norris and Kochhar, 2015). Oleh karena itu, setiap Muslim memiliki kewajiban dan tanggung jawab untuk membantu orang lain, termasuk kepada nonMuslim.

Seperti negara berkembang lainnya, Indonesia sebagai negara berpenduduk Muslim terbesar di dunia menghadapi masalah ketimpangan pendapatan yang relatif tinggi. Berdasarkan data Badan Pusat Statistik (BPS), indeks Gini Indonesia mencapai 0.41 pada tahun 2015.Bahkan, Mohieldin et al., (2012) menyatakan bahwa 73 
persen rumah tangga miskin merupakan Muslim dan tidak memiliki rekening bank. Terkait dengan hal ini, banyak penelitian terdahulu menunjukkan bahwa salah satu penyebab fenomena ketimpangan pendapatan terjadi adalah keterbatasan akses terhadap sektor keuangan (Akimov et al., 2006; Kenourgios \& Samitas, 2007; Levine, 2003; Park \& Shin, 2015).

Bank Dunia (2008 dalam Mohieldin, et.al. (2012)) membagi dua faktor financial exclusion, yaitu voluntary factor dan involuntary factor. Voluntary factor terjadi ketika non-user (bukan pengguna) secara sukarela memang tidak menggunakan jasa keuangan yang terjadi karena alasan agama atau karena mereka tidak cukup memiliki pengetahuan terkait pentingnya jasa keuangan dalam kehidupan sehari-hari. Sedangkan involuntary factor terjadi karena empat alasan. Pertama, kelompok yang dianggap tidak dapat diberikan kredit karena berpenghasilan rendah atau memiliki risiko tinggi gagal bayar. Kedua, ada diskriminasi terhadap kelompok karena latar belakang sosial, agama atau etnis yang kemudian menyebabkan mereka tidak dapat mengakses layanan keuangan. Ketiga, ada kerja kontrak atau informasi yang memiliki biaya tinggi, misalnya pinjaman membutuhkan lebih dari 1 bulan untuk diproses padahal seharusnya bisa diselesaikan dalam hitungan hari. Alasan keempat adalah tingginya harga jasa keuangan untuk kelompok-kelompok tertentu di masyarakat.

Salah satu tujuan Bank Syariah didirikan adalah menggantikan suku bunga dan menerapkan skema pembagian keuntungan dan kerugian (profit and loss sharing, PLS) di seluruh elemen masyarakat. Dalam hal ini, penerapan PLS di perbankan syariah dianggap lebih adil sehingga diharapkan dapat meningkatkan pendapatan dan distribusi kekayaan di antara inividu masyarakat (Ismail 2010; Ismail et.al. 2014). Merujuk pada tujuan utama bank syariah tersebut, maka tidak dapat dipungkiri jika semangat inklusi keuangan dan perbankan syariah diharapkan mampu untuk melayani tujuan pengajaran Islam terkait keadilan sosial, penyisipan dan distribusi sumber daya antara yang kaya dan yang miskin (Iqbal \& Mirakhor, 2013). Dengan kata lain, tujuan pendirian Bank syariah dapat dikatakan tidak hanya mengejar keuntungan saja, melainkan juga mengemban misi sosial.

Dalam konteks Indonesia, Bank syariah didirikan pertama kali pada tahun 1992 dan belum mendapatkan respon yang positif dalam industri perbankan. Pemerintah pada tahun 1998 mengesahkan UU No. 10 Tahun 1998 yang secara jelas mengakui terdapat dua sistem perbankan di Indonesia. Sejak saat itu, industri perbankan memberikan respon yang cukup baik dengan berdirinya beberapa bank syariah ditingkat daerah dan unit usaha syariah. Namun, kurang dari 2 tahun setelah UU No.21 Tahun 2008 tentang Perbankan syariah disahkan, terdapat 5 bank umum syariah (BUS) baru didirikan. Secara umum, perkembangan bank syariah di Indonesia selama lebih dari dua dekade dapat dikatakan mengalami kemajuan yang cukup berarti. Namun demikian, terdapat pertanyaan mendasar yang perlu digaris bawahi: sampai sejauh manakah inklusi keuangan bank syariah di Indonesia telah berkembang di masyarakat?

Penelitian terdahulu terkait pengukuran inklusi keuangan di Bank syariah masih sangat terbatas, terutama di Indonesia. Oleh karena itu, perkembangan inklusi keuangan di perbankan syariah di Indonesia pun juga masih terbatas. Berdasarkan hal tersebut, penelitian ini bertujuan untuk menganalisi pengaruh regional keuangan inklusif pada perbankan syariah terhadap ketimpangan pendapatan di Indonesia. Hasil estimasi didapat dengan melakukan regresi hasil indeks keuangan inklusi syariah dua dimensi dengan indikator ketimpangan pendapatan dan variabel ekonomi lain. Dengan demikian hasil dari penelitian ini dapat digunakan untuk memperkirakan efektivitas strategi keuangan inklusif untuk mengurangi ketimpangan pendapatan, terutama di Indonesia.

\section{Metode Penelitian}

Penelitian ini mengunakan data sekunder, yaitu data cross section provinsi dari tahun 2014-2016. Sampel dalam penelitian ini adalah 33 Provinsi di Indonesia. Data sekunder diperoleh dari Otoritas Jasa Keuangan, BPS dan literatur-literatur lain yang masih berhubungan dengan penelitian. Adapun data yang digunankan dalam penelitian ini, sebagai berikut:

1. data jumlah kantor layanan Bank Umum Syariah (BUS), Unit Usaha Syariah (UUS), dan Bank Pembiayaan Rakyat Syariah (BPRS)per provinsi;

2. data jumlah Dana Pihak Ketiga BUS, UUS, dan BPRS per provinsi;

3. data jumlah pembiyaan BUS, UUS dan BPRS per provinsi; dan

4. data Produk Doestik Regional Bruto per provinsi.

5. data Produk Doestik Regional Brutoper kapita per provinsi

6. data Gini Rasio per provinsi

7. data jumlah penduduk miskin per provinsi

8. data harapan lama sekolah per provinsi

Pengukuran indeks keuangan inklusi yang dipergunakan dalam penelitian ini merujuk dari penelitian Sarma $(2008,2012)$ dan disesuaikan dengan kondisi di tingkat provinsi. Pendekatan perhitungan indeks dalam 
penelitianan ini mirip dengan UNDP seperti perhitungan Human Development Index (HDI). Perhitungan dari IKI dimulai dengan menghitung indeks dari berbagai aspek keuangan inklusi.

$d_{i}=\frac{A_{i}-m_{i}}{M_{i}-m_{i}}$

Keterangan

$\mathrm{A}_{\mathrm{i}}=$ Nilai Aktual dari dimensi $\mathrm{i}$

$\mathrm{mi}=$ Nilai Minimum dari dimensi i

$\mathrm{Mi}=$ Nilai Maksimum dari dimensi i

Indeks Keuangan Inklusi (IKI) sebagai berikut

$I K I_{i}=1-\frac{\sqrt{\left(1-d_{1}\right)^{2}+\left(1-d_{2}\right)^{2}+\cdots\left(1-d_{n}\right)^{2}}}{\sqrt{n}}$

Indeks keuangan inklusi menurut Sarma $(2008,2012)$ terdiri 3 demensi dari sistem keuangan: penetrasi perbankan (PP), ketersediaan pelayanan perbankan (KPP) dan penggunaan jasa perbankan (PJP). Namun, penelitian ini menggunakan 2 dimensi yaitu, (1) Dimensi Ketersediaan Pelayanan Perbankan, jumlah kantor cabang Bank Umum Syariah, Unit Usaha Syariah dan Bank Perkreditan Rakyat Syariah (per 100.000 penduduk) untuk mengukur dimensi ketersediaan Pelayanan Perbankan untuk provinsi di Indonesia, (2) Dimensi Penggunaan Jasa Perbankan, volume dana pihak ketiga dan pembiayaan sebagai proporsi PDRB provinsi digunakan untuk mengukur dimensi penggunaan untuk provinsi di Indonesia.

Nilai indeks keuangan inklusi berada antara 0 dan 1 . Nilai IKI $=1$ menunjukkan provinsi itu memiliki kondisi keuangan inklusi terbaik di antara provinsi yang lain. Sebaliknya, nilai IKI=0 menunjukkan provinsi tesebut memiliki kondisi keuangan inklusi paling buruk. Tingkat inklusi keuangan semakin baik, jika nilai indeks inklusi keuangan mendekati 1 . Nilai indeks keuangan inklusi dikelompokkan ke dalam tiga kategori. Tingkat inklusi keuangan tinggi jika nilai indeks keuangan inklusi $0,6<\mathrm{IKI} \leq 1$, tingkat keuangan inklusi sedang jika nilai indeks keuangan inklusi $0,3 \leq \mathrm{d} \leq 0,6$, dan tingkat keuangan inklusi rendah jika nilai indeks $\leq 0,3$.

Model ekonometrik dalam penelitian ini menggunakan regresi data panel yang mencakup tahun 2014 hingga 2016. Terdapat 4 variabel yang akan digunakan dalam regresi panel data, sebagai berikut:

$\operatorname{logGINI} I_{i, t}=\alpha+\beta_{1} \log \mathrm{IKI}_{\mathrm{i}, \mathrm{t}}+\beta_{2} \operatorname{logPDRB} \mathrm{i}_{\mathrm{i}, \mathrm{t}}+\beta_{3} \operatorname{logPOV} \mathrm{V}_{\mathrm{i}, \mathrm{t}}+\beta_{4} \operatorname{logHLS} \mathrm{S}_{\mathrm{i}, \mathrm{t}}+\varepsilon_{\mathrm{i}, \mathrm{t}}$

Tabel 1. Pengukuran Variabel

\begin{tabular}{|c|c|c|c|}
\hline Variabel & Simbol & Ukuran & Sumber \\
\hline $\begin{array}{r}\text { Ketimpangan } \\
\text { Pendapatan } \\
\end{array}$ & GINI & Gini index data & BPS \\
\hline \multicolumn{4}{|l|}{ Financial Development } \\
\hline Keuangan Inklusi & IKI & $\begin{array}{l}\text { Indeks Keuangan Inklusi } \\
\text { Perbankan Syariah }\end{array}$ & Perhitungan penulis \\
\hline \multicolumn{4}{|l|}{ Control Variables } \\
\hline $\begin{array}{r}\text { Pertumbuhan } \\
\text { ekonomi }\end{array}$ & PDRB & $\begin{array}{l}\text { PDRB per kapita Atas dasar } \\
\text { Harga Konstan } 2010\end{array}$ & BPS \\
\hline Kemiskinan & $\mathrm{POV}$ & Jumlah penduduk miskin & BPS \\
\hline Pendidikan & HLS & Harapan lama sekolah & BPS \\
\hline
\end{tabular}

\section{Analisis dan Pembahasan}

Hasil perhitungan IKI di 33 provinsi di Indonesia dibentuk dari 2 dimensi yaitu dimensi Ketersediaan Pelayanan Perbankan dan dimensi Kegunaan Jasa Perbankan. Penelitian ini membagi nilai indeks keuangan inklusi menjadi 3 kategori, yaitu tinggi $(0,6<\mathrm{FII} \leq 1)$, sedang $(0,3<\mathrm{FII} \leq 6)$, dan rendah $(\mathrm{FII} \leq 3)$. Berdasarkan nilai indeks keuangan inklusi, sebesar 84,8 persen atau sebanyak 28 provinsi dikategorikan memiliki indeks keungan inklusi rendah. Provinsi yang dikategorikan memiliki indeks keuangan inklusi sedang, sebesar 15,2 persen atau sebanyak 5 provinsi, yaitu Jawa Barat dengan rata-rata sebesar 0,41079, Jawa Tengah dengan rata-rata sebesar 0,33741, Jawa Timur dengan rata-rata sebesar 0,3479, D.I Yogyakarta dengan rata-rata sebesar 0.31334, dan Bangka Belitung dengan rata-rata sebesar 0.3076 . 
Tabel 2. Regional Indeks Keuangan Inklusi Perbankan Syariah

\begin{tabular}{clcccc}
\hline No. & Provinsi & 2014 & 2015 & 2016 & Rata-rata \\
\hline 1. & Jawa Barat & 0.40719 & 0.41121 & 0.41397 & 0.41079 \\
2. & Banten & 0.23381 & 0.23838 & 0.23552 & 0.23590 \\
3. & DKI Jakarta & 0.29354 & 0.27839 & 0.29035 & 0.28743 \\
4. & D.I Yogyakarta & 0.29420 & 0.30865 & 0.33716 & 0.31334 \\
5. & Jawa Tengah & 0.33592 & 0.33901 & 0.33729 & 0.33741 \\
6. & Jawa Timur & 0.35134 & 0.35271 & 0.33967 & 0.34790 \\
7. & Bengkulu & 0.18448 & 0.17262 & 0.18006 & 0.17905 \\
8. & Jambi & 0.02986 & 0.03432 & 0.02892 & 0.03103 \\
9. & Aceh & 0.17033 & 0.18103 & 0.29838 & 0.21658 \\
10. & Sumatera Utara & 0.19018 & 0.19247 & 0.17002 & 0.18422 \\
11. & Sumatera Barat & 0.16569 & 0.16047 & 0.14565 & 0.15727 \\
12. & Riau & 0.08926 & 0.07969 & 0.07032 & 0.07976 \\
13. & Sumatera Selatan & 0.09731 & 0.09201 & 0.08050 & 0.08994 \\
14. & Bangka Belitung & 0.30690 & 0.30676 & 0.30915 & 0.30760 \\
15. & Kepulauan Riau & 0.06102 & 0.06433 & 0.07058 & 0.06531 \\
16. & Lampung & 0.14184 & 0.14407 & 0.17726 & 0.15439 \\
17. & Kalimantan Selatan & 0.08281 & 0.08275 & 0.05885 & 0.07480 \\
18. & Kalimantan Barat & 0.04463 & 0.04898 & 0.04073 & 0.04478 \\
19. & Kalimantan Timur & 0.09012 & 0.08934 & 0.07270 & 0.08405 \\
20. & Kalimantan Tengah & 0.03236 & 0.03488 & 0.03447 & 0.03390 \\
21. & Sulawesi Tengah & 0.02009 & 0.01986 & 0.02316 & 0.02104 \\
22. & Sulawesi Selatan & 0.14651 & 0.14963 & 0.12059 & 0.13891 \\
23. & Sulawesi Utara & 0.00994 & 0.00987 & 0.01151 & 0.01044 \\
24. & Gorontalo & 0.00070 & 0.00059 & 0.00048 & 0.00059 \\
25. & Sulawesi Barat & 0.00029 & 0.00512 & 0.00135 & 0.00225 \\
26. & Sulawesi Tenggara & 0.02491 & 0.02464 & 0.02872 & 0.02609 \\
27. & Nusa Tenggara Barat & 0.16611 & 0.16463 & 0.15713 & 0.16262 \\
28. & Bali & 0.04106 & 0.04119 & 0.03628 & 0.03951 \\
29. & Nusa Tenggara Timur & 0.00494 & 0.00489 & 0.00573 & 0.00519 \\
30. & Maluku & 0.00032 & 0.00033 & 0.00035 & 0.00033 \\
31. & Papua & 0.00569 & 0.00541 & 0.00607 & 0.00572 \\
32. & Maluku Utara & 0.04296 & 0.05755 & 0.07821 & 0.05957 \\
33. & Papua Barat & 0.00007 & 0.00008 & 0.00011 & 0.00009 \\
\hline Sumber & perhitungan penulis & & & &
\end{tabular}

Sumber : perhitungan penulis

Provinsi yang memiliki indeks keuangan inklusi sedang adalah Jawa Barat, Jawa Timur, Jawa Tengah, dan Bangka Belitung untuk tahun 2014. Sementara itu, tahun 2015 dan 2016 bertambah Daerah Istimewa Yogyakarta masuk dalam kategori sedang. Berdasarkan nilai dimensi dari Indeks Keuangan Inklusi, sebaran nilai dimensi keuangan inklusi Provinsi Jawa Barat lebih tinggi dari provinsi lainnya.

Tabel 3. Deskriptif Statistik

\begin{tabular}{lccccc}
\hline & GINI & IKI & PDRB & POV & HLS \\
\hline Rata-rata & 0.368455 & 0.128621 & 36993.47 & 847.654 & 12.649 \\
Maksimum & 0.459000 & 0.413970 & 149779.4 & 4775.97 & 15.230 \\
Minimum & 0.275000 & $7.00 \mathrm{E}-05$ & 10742.32 & 66.620 & 9.940 \\
Std. Dev. & 0.040849 & 0.118965 & 29096.72 & 1217.332 & 0.809 \\
\hline Jumlah & 99 & 99 & 99 & 99 & \multirow{2}{*}{99} \\
observasi & & & & &
\end{tabular}

Sumber: Otoritas Jasa Keuangan dan Badan Pusat Statistik. Diolah.

Tabel 3 menunjukkan rata-rata Gini pada tahun yang diamati adalah 0.368 dengan standar deviasi sebesar 0.040. Variabel Ginimemiliki nilai minimum sebesar 0.275 dan nilai maksimum sebesar 0.459 . Sementara itu, rata-rata IKI provinsi pada tahun yang diamati adalah 0.128 dengan standar deviasi sebesar 0.118 . Variabel IKI memiliki nilai minimum sebesar 0.00007 dan nilai maksimum sebesar0.413.

Rata-rata PDRB per kapita (PDRB) pada tahun yang diamati adalah 36993.47juta rupiahdengan standar deviasi sebesar 29096.72 juta rupiah. PDRB per kapita memiliki nilai minimum sebesar 10742.32 juta rupiah dan 
nilai maksimum sebesar 149779.4 juta rupiah. Rata-rata jumlah penduduk miskin (POV) pada tahun yang diamati sebesar 847.64 ribu penduduk dengan standar deviasi sebesar 1217.33 ribu penduduk. Nilai maksimum jumlah penduduk miskin sebesar 4775.97 ribu penduduk dan nilai minimum sebesar 66.62 ribu penduduk. Rata-rata Harapan Lama Sekolah provinsi di Indonesia pada tahun yang diamati adalah 12.649 tahun dengan standar deviasi sebesar0.809 tahun. Variabel HLS memiliki nilai minimum sebesar 9.940 tahun dan nilai maksimum sebesar 15.230 tahun .

Tabel 4. Hasil Regresi PanelLeast Squares Gini(log)

\begin{tabular}{|c|c|c|c|c|}
\hline Variabel & (1) & (2) & (3) & (4) \\
\hline \multirow[t]{2}{*}{$\mathrm{C}$} & $-1.027 * * *$ & $-1.340 * * *$ & $-1.793 * * *$ & $-1.858 * * *$ \\
\hline & {$[-51.72]$} & {$[-6.26]$} & [-8.02] & {$[-3.57]$} \\
\hline \multirow[t]{2}{*}{ IKI (log) } & -0.007 & -0.008 & $-0.016 * * *$ & $-0.016^{* * *}$ \\
\hline & {$[-1.41]$} & {$[-1.56]$} & {$[-3.00]$} & {$[-2.95]$} \\
\hline \multirow{2}{*}{ PDRB (log) } & & 0.030 & $0.045 * *$ & $0.046 * *$ \\
\hline & & [1.45] & [2.37] & [2.33] \\
\hline \multirow[t]{2}{*}{ POV (log) } & & & $0.044 * * *$ & $0.044 * * *$ \\
\hline & & & [4.27] & [4.24] \\
\hline \multirow[t]{2}{*}{ HLS (log) } & & & & 0.022 \\
\hline & & & & [0.13] \\
\hline R-squared & 0.020 & 0.041 & 0.19 & 0.196 \\
\hline observasi & 99 & 99 & 99 & 99 \\
\hline provinsi & 33 & 33 & 33 & 33 \\
\hline tahun & 2014-2016 & 2014-2016 & 2014-2016 & 2014-2016 \\
\hline
\end{tabular}

Keterangan: nilai dalam kurung buka adalah t-stat.

$* * * * *$,dan * signifikan pada $\mathrm{p}<0.01, \mathrm{p}<0.05$ dan $\mathrm{p}<0.10$

Sumber: Estimasi penulis

Tabel 4. menunjukkan hasil regresi panel 31 provinsi di Indonesia dari tahun 2014 hingga 2016. Berdasarkan hasil regresi model 1 dan 2 menunjukkan variabel keuangan inklusi pada perbankan Islam tidak signifikan terhadap gini. Sebaliknya pada model 3 dan 4 keuangan inklusi pada perbankan Islam memiliki hubungan negatif dan signifikan terhadap gini atau dapat di interpretasikan bahwa ketika keuangan inklusi pada perbankan mengalami kenaikan, maka ketimpangan pendapatan juga mengalami penurunan. Temuan tersebut selaras dengan Herrero dan Turegano (2015) yang menyatakan bahwa keuangan inklusi berkontribusi untuk mengurangi ketimpangan pendapatan. Selain itu, temuan Park dan Mercado (2015); Neaime dan Gaysset (2018) menunjukan bahwa keuangan inklusi dapat menurunkan ketimpangan pendapatan.

Variabel PDRB yang merefleksikan pertumbuhan ekonomi juga menunjukkan hubungan positif dan signifikan terhadap ketimpangan pendapatan. Seperti yang telah dijelaskan oleh Kuznet (1955) bahwa secara umum pada fase awal pembangunan di Negara-negara berkembang (termasuk Indonesia), pertumbuhan ekonomi yang tinggi akan menyebabkan kenaikan ketimpangan pendapatan. Aghion dan Bolton (1997) juga mendukung argumen bahwa tambahan kekayaan yang didapat oleh kelompok berpenghasilan tinggi merupakan pertanda baik untuk kelompok berpenghasilan rendah. Namun demikian, hasil studi (Berg \& Ostry, 2011; Berg, Ostry, \& Zettelmeyer, 2012; Ostry, Berg, \& Tsangarides, 2014) menunjukkan bahwa dalam jangka panjang peningkatan ketimpangan pendapatan akan menyebabkan ketidakstabilan ekonomi. Oleh karena itu, hubungan positif antara PDRB dengan ketimpangan pendapatan perlu segera diwaspadai terutama dalam jangka panjang agar dapat mencegah terjadinya ketidakstabilan ekonomi.

Pada model 3 dan 4 menunjukkan bahwa hubungan positif dan signifikan jumlah penduduk miskinterhadap ketimpangan pendapatan. Peningkatan jumlah penduduk miskin berkontribusi pada meningkatnya ketimpangan pendapatan. Sementara itu, tingkat pendidikan (HLS) secara statistik tidak signifikan. Hal ini mungkin disebabkan karena sebagian penduduk Indonesia menyelesaikan pendidikan formalnya pada tingkat sekolah menengah pertama. Hanya sebagian kecil dari penduduk Indonesia yang mengenyam pendidikan perguruan tinggi.

\section{Kesimpulan}

Penelitian ini bertujuan untuk menganalisis pengaruh regional keuangan inklusif pada perbankan syariah terhadap ketimpangan pendapatan di Indonesia. Studi kasus dilakukan lintas 33 provinsi dari tahun 2014 hingga 2016 dengan menggunakan Panel least squares. Hasil dari penelitian ini menunjukan bahwa keuangan inklusi pada perbankan syariah memiliki pengaruh negative terhadap ketimpangan pendapatan. keuangan inklusi berkontribusi 
untuk mengurangi ketimpangan pendapatan. Hasil ini menegaskan kembali bahwa diperlukannya dukungan penuh dari pemerintah untuk semakin mengembankan perbankan

Implikasi dan saran yang dapat diberikan dalam penelitian ini yaitu pemerintah perlu membuat kebijakan yang dapat mendorong keuangan inklusif semakin berkembang, terutama di daerah-daerah terpencil di Indonesia. Oleh karena itu diperlukan alternatif di sektor perbankan untuk membuka branchless banking di desa-desa. Branchless banking merupkan salah satu cara untuk mempermudah masyarakat dalam mengakses jasa keuangan tanpa bergantung pada keberadaan fisik sebuah bank di sebuah daerah. Akhirnya, hasil penelitian ini dapat membantu mengembangkan kebijakan yang lebih baik untuk mereformasi sektor keuangan dengan menunjukkan bagaimana memperluas penggunaan layanan perbankan dapat berdampak langsung pada distribusi pendapatan.

\section{Daftar Pustaka}

Aghion, P. \& Bolto, P. (1997). A Theory of Trickle-Down Growth and Development. The Review of Economic Studies, 64 (2), 151-172

Akimov, A., Wijeweera, A., \& Dollery, B. (2006). Finance-Growth Nexus: Evidence from Transition Economies. Economics Working Paper Series, (2006-5).

Berg, A., \& Ostry, J. (2011). Inequality and Unsustainable Growth: Two Sides of the Same Coin? International Monetary Fund Staff Discussion Note, 1-21. https://doi.org/10.1017/CBO9781107415324.004

Berg, A., Ostry, J. D., \& Zettelmeyer, J. (2012). What makes growth sustained? Journal of Development Economics, 98(2), 149-166.

Dabla-norris, E., \& Kochhar, K. (2015). Causes and Consequences of Income Inequality: A Global Perspective (June 2015 No. SDN/15/13).

García-Herrero, A., \& Turégano, D. M. (2015). Financial inclusion, rather than size, is the key to tackling income inequality. BBVA Research Working Paper, 15(05).

Haughton, J., \& Khandker, S. R. (2009). Handbook on Poverty and Inequality. The World Bank.

Hannig, Alfred \& Jansen, Stefan, Financial Inclusion and Financial Stability: Current Policy Issues (December 21, 2010). ADBI Working Paper No.259.

Ismail, A. G. (2010). Islamic banks and wealth creation. International Shari'ah Reseach Academy for Islamic Finance (ISRA) Journal, 9, 1-16.

Ismail, A. G., Akbar, S., \& Ngalim, S. M. (2014). Measuring the Value of Islamic Banks. Irti Working Paper Series, (1435-13), 28.

Iqbal, Z., \& Mirakhor, A. (2013). Economic Development and Islamic Finance. https://doi.org/10.1596/978-08213-9953-8

Kenourgios, D., \& Samitas, A. (2007). Financial development and economic growth in a transition economy: Evidence for Poland. Journal of Financial Decision Making, 3(1), 35-48.

Kuznets, S. (1955). Economic growth and income inequality. The American economic review, 45(1), 1-28.

Levine, R. (2003). More on finance and growth: more finance, more growth?. Review-Federal Reserve Bank Of Saint Louis, 85(4), 31-46.

Mohieldin, M., Iqbal, Z., Rostom, A., \& Fu, X. (2011). The role of Islamic finance in enhancing financial inclusion in Organization of Islamic Cooperation (OIC) countries. The World Bank.

Neaime, S., \& Gaysset, I. (2018). Financial inclusion and stability in MENA: Evidence from poverty and inequality. Finance Research Letters, 24, 230-237.

Ostry, M. J. D., Berg, M. A., \& Tsangarides, M. C. G. (2014). Redistribution, inequality, and growth. International Monetary Fund.

Park, C. Y., \& Mercado, R. (2015). Financial inclusion, poverty, and income inequality in developing Asia. ADBEconomics Working Paper Series, 426, (2015)

Park, D., \& Shin, K. (2017). Economic growth, financial development, and income inequality. Emerging Markets Finance and Trade, 53(12), 2794-2825. 
Pramanik, Ataul Huq. (1993). Development and Distribution in Islam. Kuala Lumpur: Pelanduk Press.

Sarma, M. (2008). Index of financial inclusion. ICRIER Working Papper, 215.

Sarma, M. (2012). Index of Financial Inclusion-A measure of financial sector inclusiveness. Money, Trade, Finance, and Development Competence Centerin cooperation with DAAD Partnership and Hochschule für Technik und Wirschaft Berlin University of Applied Sciences. Working Paper, (07).

Todaro, M. P., \& Smith, S. C. (2015). Economic Development. Pearson. https://doi.org/10.1017/CBO9781139028295

Yorulmaz, Recep. "Construction of a regional financial inclusion index in Turkey." Journal of BRSA Banking and Financial Markets 7, no. 1 (2013): 79-101. 